\title{
POTENSI GANGGUAN AREA ON STREET PARKING TERHADAP KINERJA JALAN DI KAWASAN KOMERSIAL (KASUS : JALAN PEMUDA KOTA MAGELANG)
}

Muhammad Anwan Burhani', Galing Yudana', Paramita Rahayu1

1Program Studi Perencanaan Wilayah dan Kota Fakultas Teknik Universitas Sebelas Maret Surakarta

\begin{abstract}
Abstrak
Kota merupakan konsentrasi penduduk dalam suatu wilayah geografis tertentu yang mampu menghidupi dirinya sendiri melalui kegiatan ekonomi. Kawasan pecinan telah dikenal secara luas di Indonesia sebagai domain ekonomi atau pusat aktivitas komersial. Jalan Pemuda di Kota Magelang merupakan kawasan pecinan dengan aktivitas komersial yang berkembang pesat. Perkembangan aktivitas komersial ini manimbulkan tarikan pergerakan yang tinggi. Konsekuensinya permintaan parkir pada kawasan komersial tersebut meningkat. On street parking terjadi karena tidak adanya fasilitas off street parking. On street parking di Jalan Pemuda adalah on street parking terpanjang dan paling masif di Kota Magelang. Selain itu Jalan Pemuda adalah jalan utama Kota Magelang yang melintasi pusat kota dengan volume lalu lintas yang tinggi. Oleh sebab itu memahami potensi gangguan on street parking yang masif terhadap kinerja jalan pada kawasan seperti ini adalah hal penting. Metode yang digunakan pada penelitian ini adalah analisis deskriptif kuantitatif dengan menggunakan 4 variabel on street parking (volume parkir, kapasitas parkir, durasi parkir dan sudut parkir) dan 2 variabel kinerja jalan (volume lalu lintas dan kapasitas jalan) serta proses analisis triangulasi untuk mengetahui potensi gangguan on street parking terhadap kinerja jalan pada kawasan komersial. Triangulasi metode pengumpulan data dilakukan dengan observasi lapangan, wawancara dan kuesioner. Hasil dari penelitian ini mengungkapkan bahwa volume parkir, durasi parkir dan sudut parkir mengurangi lebar jalan sebesar $70 \%$ dan menyisakan 30\% lebar efektif jalan. Hal tersebut menyebabkan on street parking di Jalan Pemuda Kota Magelang memberikan tingkat gangguan yang tinggi terhadap kinerja jalan. Oleh sebab itu sangat penting untuk mencari alternatif lokasi off street parking untuk mengakomodasi parkir di Jalan Pemuda untuk menghindari kemacetan di jalan utama Kota Magelang.
\end{abstract}

Kata kunci : kawasan komersial, kinerja jalan, on street parking.

\begin{abstract}
City is the concentration of the population within a certain geographical region capable of supporting itself through economic activity. Chinatown has been widely recognized in Indonesia as an economic domain or a center of commercial activity. Pemuda Street in Magelang City is a Chinatown with fast growing commercial activity. The development of this commercial activity led to the pull of high movement. Consequently demand for parking in the commercial area is increasing. On street parking occurred due to the absence of off street parking facilities. On street parking at Pemuda Street is the longest and most massive on street parking in Magelang City. Besides, Pemuda Street is the main road of Magelang City that passes downtown with high traffic volume. Therefore, understanding the potential for massive on-street parking disruption of road performance in such areas is important. The method used in this research is quantitative descriptive analysis using 4 variables on street parking (parking volume, parking capacity, parking duration and parking angle) and 2 variable of road performance (traffic volume and road capacity) and triangulation analysis to know the potential of on-street parking disruption to road performance in commercial area. Triangulation of data collection method is done by field observation, interview and questionnaire. The results of this study revealed that parking volume, parking duration and parking angle reduced the road width by $70 \%$ and left $30 \%$ effective width of the road. This causes on street parking at Jalan Pemuda Kota Magelang to provide a high level of disturbance to road performance. Therefore it is very important to find an alternative location off street parking to accommodate parking on Jalan Pemuda to avoid congestion on the main road of Magelang city.
\end{abstract}

Keywords : commercial area, on street parking, road performance 


\section{PENDAHULUAN}

Kota merupakan konsentrasi penduduk dalam suatu wilayah geografis tertentu yang menghidupi dirinya sendiri secara relatif permanen dari kegiatan ekonomi (komersial) yang ada di wilayah tersebut (Gallion, 1992). Aktivitas komersial memiliki jumlah pergerakan rata-rata 136 pergerakan per $100 \mathrm{~m}^{2}$ untuk swalayan, 85 pergerakan per $100 \mathrm{~m}^{2}$ untuk pertokoan lokal dan 38 pergerakan per $100 \mathrm{~m}^{2}$ untuk pusat pertokoan (Tamin, 2010). Kawasan komersial akan menimbulkan tarikan, sehingga memerlukan fasilitas pendukung lainnya seperti fasilitas transportasi. Fasilitas transportasi yang kurang memadai di kawasan komersial mengakibatkan menurunnya kinerja jalan yang berdampak pada kemacetan. Seperti halnya parkir di badan jalan dapat menyebabkan kemacetan jika tidak diatur dengan baik dan benar.

Kota Magelang terletak di tengah-tengah wilayah Kabupaten Magelang, sebelah utara berbatasan dengan Kecamatan Secang, sebelah timur dengan Kecamatan Tegalrejo, sebelah selatan dengan Kecamatan Mertoyudan dan

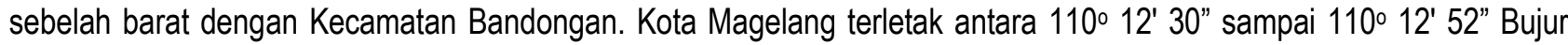
Timur dan antara 70 26' 18" sampai 70 30' 9" Lintang Selatan. Kota Magelang memiliki wilayah seluas 18,12 km² yang terbagi dalam tiga kecamatan yaitu Kecamatan Magelang Utara, Kecamatan Magelang Tengah dan Kecamatan Magelang Selatan. Kota Magelang merupakan persilangan jalur transportasi utama Semarang-Yogyakarta. Posisi Magelang berada $75 \mathrm{~km}$ di selatan Kota Semarang dan $43 \mathrm{~km}$ di utara Kota Yogyakarta. Kota Magelang juga terletak pada jalur ekonomi Semarang-Yogyakarta-Purworejo dan jalur wisata Yogyakarta-Borobudur-Kopeng dan dataran tinggi Dieng.

Jalan Pemuda merupakan jalan arteri sekunder yang berada di Kelurahan Panjang dan Kelurahan Kemirirejo, Kecamatan Magelang Tengah. Ruas jalan ini merupakan akses utama untuk keluar dari Kota Magelang untuk menuju Yogyakarta. Selain itu ruas jalan ini merupakan pusat perdagangan di Kota Magelang. Jalan Pemuda merupakan kawasan pemukiman Thionghoa atau pecinan. Kawasan pecinan telah dikenal secara luas sebagai domain ekonomi kota, di nusantara memiliki tipikal kawasan pecinan yang berfungsi sebagai pusat ekonomi (komersial) (Farida 2013). Lokasi kawasan komersial Jalan Pemuda merupakan CBD dengan karakter khas Thionghoa, dekat dengan Alun Alun Kota Magelang. Panjang Jalan Pemuda adalah 832 meter perkembangan aktivitas komersial dari tahun 2012-2016 adalah sebagai berikut;

Tabel 1. Perkembangan Aktivitas Komersial Jalan Pemuda Kota Magelang

\begin{tabular}{|c|l|c|}
\hline No & \multicolumn{1}{|c|}{ Perkembangan } & Prosentase \\
\hline 1. & Jumlah perdagangan dan jasa & $23,3 \%$ \\
\hline 2. & Luas lahan komersial & $2,6 \%$ \\
\hline 3. & Luas lantai komersial & $8,67 \%$ \\
\hline 4. & Jumlah komoditas komersial & $18,75 \%$ \\
\hline
\end{tabular}

Sumber : Diskoperindag

Tabel perkembangan aktivitas komersial di Jalan Pemuda menunjukkan adanya peningkatan aktivitas komersial dari tahun 2012 hingga 2016. Konsekuensinya permintaan parkir di kawasan ini meningkat. Tidak adanya ruang parkir yang memadai menyebabkan terjadinya on street parking di Jalan Pemuda Kota Magelang. Panjang Jalan Pemuda adalah 832 meter dengan lebar 6,5 meter dengan bahu jalan sebesar 4 meter yang digunakan untuk on street parking. Adanya on street parking masif di Jalan Pemuda berpotensi mengganggu kinerja Jalan Pemuda Kota Magelang. Di Jalan Pemuda Kota Magelang sebagai jalan arteri sekunder dengan koridor komersial yang terdapadat on street parking. On street parking ini berpotensi mengganggu kinerja jalan. Oleh sebab itu tujuan penelitian ini adalah mengetahui potensi gangguan area on street parking terhadap kinerja jalan di kawasan komersial Jalan Pemuda Kota Magelang. Penelitian ini dapat menggambarkan perbedaan kinerja jalan dengan ada on street parking dan tanpa ada on street parking serta berguna bagi pengambil kebijakan untuk menentukan kebijakan dan rencana penataan kawasan komersial di Jalan Pemuda Kota Magelang. Selain itu dapat mendukung rencana Walikota Magelang untuk membuat kawasan city walk pada kawasan komersial Jalan Pemuda Kota Magelang. 


\section{KAJIAN TEORI}

Kajian pustaka ini berisi mengenai kebijakan dan studi yang telah dilakukan sebelumnya terkait dengan parkir dikawasan komersial, aktivitas komersial, on street parking, dan kinerja jalan sebagai berikut

\subsection{AKTIVITAS KOMERSIAL}

Aktivitas perekonomian perdagangan dan jasa (komersial) adalah sektor yang paling mudah tumbuh ditempattempat strategis. Aktivitas komersial merupakan tatanan kegiatan yang terkait dengan transaksi barang dan jasa. Perkembangan aktivitas komersial yang berkembang sepanjang jalan akan melahirkan koridor kawasan komersial. Koridor jalan komersial merupakan koridor jalan yang pemanfaatan ruang di sepanjang jalannya untuk kegiatan komersial, perkantoran yang kompleks dan pusat pekerjaan di dalam kota (Bishop dalam Djaelani, 2013). Kawasan komersial ini memiliki pengaruh besar terhadap ekonomi kota. Menurut Permen PU No 29/PRT/M/2006, setiap bangunan bukan rumah hunian diwajibkan menyediakan area parkir kendaraan yang proporsional dengan jumlah luas lantai bangunan. Selanjutnya, permen PU No 29/PRT/M/2006 mengatur bahwa prasarana parkir suatu rumah atau bangunan tidak diperkenankan mengganggu kelancaran lalu lintas, atau mengganggu lingkungan di sekitarnya.

\subsection{TRANSPORTASI}

Transportasi merupakan sistem jaringan fisik yang menghubungkan ruang kegiatan yang berguna untuk memindahkan barang dan dapat menciptakan kegunaan waktu dan tempat. Transportasi merupakan sistem jaringan yang secara fisik menghubungkan satu ruang kegiatan dengan ruang kegiatan lainnya (Tamin, 2000). Sistem jaringan ini kadang memiliki gangguan seperti kemacetan sehingga menimbulkan tundaan perjalanan. Penundaan ini ditimbulkan oleh kelambatan atau macetnya kendaraan pada simpang jalan yang terlalu ramai dengan kendaraan, lebar jalan yang kurang, parkir-parkir mobil di jalan sempit dan sebagainya (Fauzia, 2013).

\subsection{ON STREET PARKING}

Kendaraan yang berhenti sementara waktu (menurunkan muatan) atau berhenti cukup lama yang disebut parkir (Warpani dalam Ismanto, 2008). Fasilitas parkir digolongkan dalam parkir di badan jalan (on street parking) dan parkir tidak di badan jalan (off street parking). Parkir di badan jalan akan mengurangi kapasitas jalan dan akan menyebabkan penurunan kecepatan bagi kendaraan yang melaluinya (Tamin, 2000). Menurut Jaya Wikrama (2010), karakteristik parkir dapat diketahui melalui volume parkir, lama waktu parkir, kapasitas parkir, dan indek parkir. Selain karakteristik tersebut hal yang berpengaruh lainnya adalah sudut parkir. Sudut parkir berpengaruh dalam banyaknya ruang yang dibutuhkan untuk parkir dan manuver (Direktorat Jendral Perhubungan Darat, 1998). Standar satuan luasan parkir disebut satuan ruas parkir (SRP), satuan ini merupakan ketetapan dari Direktorat Jendral Perhubungan Darat tahun 1998. Semakin besar sudut parkir kendaraan, semakin besar pula pengurangan kapasitas jalannya. Penurunan kapasitas jalan bukan saja disebabkan oleh pengurangan lebar jalan tetapi juga oleh proses kegiatan kendaraan masuk dan keluar petak parkir (Tamin, 2000).

Terkait dengan on street parking menurut Keputusan Dirjen Jendral Perhubungan Darat tentang Pedoman Teknik Penyelenggaraan Fasilitas Parkir (1998), lokasi berhenti dan parkir pada badan jalan sangat dibatasi dan seharusnya tidak diijinkan pada jam sibuk. Jenis parkir seperti ini tidak diperkenankan untuk menggunakan lebar jalan efektif. Khusus untuk konteks Kota Magelang, Perda Kota Magelang No 15 Tahun 2012 tentang Penyelenggaraan Fasilitas Parkir menyebutkan fasilitas parkir di rumija harus dapat menjamin keamanan, keselamatan dan kelancaran lalu lintas.

\subsection{KINERJA JALAN}

Kinerja ruas jalan mempengaruhi perkembangan suatu kota. Lancarnya pergerakan aktivitas mengakibatkan pendapatan ekonomi masyarakat akan meningkat. Proses perputaran roda ekonomi pun semakin lancar. Kinerja ruas jalan dipengaruhi oleh hal berikut :

\section{- Volume Kendaraan}

Volume lalu lintas menunjukan jumlah kendaraan yang melintasi satu titik pengamatan dalam satu satuan waktu (hari, jam, menit). Volume kendaraan diterjemahkan dalam satuan mobil penumpang (SMP). SMP (satuan mobil 
penumapang) adalah satuan untuk arus lalu lintas yang berbagai tipe kendaraan diubah menjadi arus kendaraan ringan (termasuk mobil penumpang) dengan menggunakan emp (MKJl, 1997). Emp (ekivalensi mobil penumpang) merupakan faktor yang menunjukkan berbagai tipe kendaraan dibandingkan kendaraan ringan sehubungan dengan pengaruhnya terhadap kecepatan kendaraan ringan dalam arus lalu lintas (untuk mobil penumpang dan kendaraan ringan yang sasisnya mirip, emp $=1,0)$ (MKJI, 1997). Berikut merupakan tabel persamaan faktor emp.

Tabel 2. Faktor Persamaan EMP

\begin{tabular}{|l|c|}
\hline \multicolumn{1}{|c|}{ Jenis kendaraan } & EMP \\
\hline Kendaraan Berat (HV) & 1,3 \\
\hline Kendaraan Ringan (LV) & 1 \\
\hline Sepeda Motor (MC) & 0,4 \\
\hline
\end{tabular}

Sumber : MKJI, 1997

Volume kendaraan dalam smp dapat dihitung sebagai berikut

Keterangan

$$
V=(e m p L V \times L V+e m p H V \times H V+e m p M C \times M C)
$$

$\mathrm{V} \quad=$ volume kendaraan $(\mathrm{smp} / \mathrm{jam})$

EmpLV = nilai emp kendaraan ringan

EmpHV = nilai emp kendaraan berat

EmpMC = nilai emp sepeda motor

$\mathrm{LV} \quad=$ notasi kendaraan ringan

$\mathrm{HV} \quad=$ notasi kendaraan berat

$\mathrm{MC}=$ notasi sepeda motor

- Kapasitas Jalan

Menurut Permen PU No. 34 Tahun 2006 tentang Jalan menyebutkan jalan arteri sekunder mempunyai kapasitas yang lebih besar daripada volume lalu lintas rata-rata. Kapasitas jalan merupakan arus lalu lintas (stabil) maksimum yang dapat dipertahankan pada kondisi tertentu (geometri, distribusi arah dan komposisi lalu lintas, faktor lingkungan) (MKJI, 1997). Kapasitas jalan dapat dihitung melalui persamaan sebagai berikut.

Keterangan

$$
C=C_{0} \times F_{c w} \times F_{c s p} \times F_{c s t} \times f F_{c s s}
$$

$\mathrm{C}=$ Kapasitas jalan (smp/jam)

Co $=$ Kapasitas dasar (smp/jam)

$\mathrm{FCw}=$ Faktor penyesuaian lebar jalan lalu lintas

$\mathrm{FCsp}=$ Faktor penyesuaian pemisah arah

FCsf = Faktor penyesuaian hambatan samping dan bahu jalan

FCcs = Faktor penyesuaian ukuran kota

- Kinerja Ruas Jalan

Kinerja ruas jalan merupakan perbandingan dari volume lalu lintas dengan kapasitas jalan (MKJI, 1997). Berikut merupakan rumus untuk menghitung VCR

Keterangan

$$
\operatorname{VCR}=\frac{V}{C}
$$

$\mathrm{VCR}=$ volume kapasitas ratio/nilai tingkat pelayanan (smp/jam)

$\mathrm{V} \quad=$ volume lalu lintas (smp/jam)

C $\quad=$ kapasitas jalan (smp/jam)

Nilai dari VCR diterjemahkan dalam nilai derajat kejenuhan sebagai berikut 
Tabel 3. Nilai Derajat Kejenuhan Jalan

\begin{tabular}{|c|l|c|}
\hline $\begin{array}{c}\text { Tingkat } \\
\text { Pelayanan }\end{array}$ & \multicolumn{1}{|c|}{ Karakteristik } & Nilai \\
\hline A & $\begin{array}{l}\text { Kondisi arus beban yang kecepatan tinggi. Pengemudi dapat memilih kecepatan yang } \\
\text { diinginkan tanpa hambatan }\end{array}$ & $0,00-0,20$ \\
\hline B & $\begin{array}{l}\text { Arus stabil tetapi kecepatan operasi mulai dibatasi oleh lalu lintas, pengemudi memliki } \\
\text { kebebasan yang cukup untuk memilih kecepatan }\end{array}$ & $0,21-0,44$ \\
\hline C & Arus stabil, akan tetapi kecepatan dan gerak kendaraan dikendalikan & $0,45-0,74$ \\
\hline D & Arus mendekati tidak stabil, kecepatan masih di kendalikan, V/C masih dapat ditolerir & $0,75-0,84$ \\
\hline E & $\begin{array}{l}\text { Volume lalu lintas mendekati atau berada pada kapasitas, arus tidak stabil, kecepatan } \\
\text { terkadang terhenti }\end{array}$ & $0,85-1,00$ \\
\hline F & $\begin{array}{l}\text { Arus dipaksakan atau macet, kecepatan rendah volume di bawah kapasitas, antrian panjang } \\
\text { dan terjadi hambatan-hambatan besar }\end{array}$ & $>1,00$ \\
\hline
\end{tabular}

Sumber : MKJI, 1997

\section{METODE PENELITIAN}

Metode penelitian yang digunakan adalah deskriptif kuantitatif untuk pembahasan terkait kinerja jalan yang dipengaruhi oleh on street parking, serta triangulasi untuk analisis potensi gangguan on street parking pada kawasan komersial terhadap kinerja jalan. Triangulasi yang digunakan adalah triangulasi metode pengumpulan data, yaitu kuesioner, observasi lapangan dan wawancara. Penelitian ini berangkat dari isu yang berkembang yang kemudian dicari teori yang terkait dengan penelitian ini. Teori yang berkaitan menghasilkan variabel-variabel. Terdapat empat variabel on street parking dan dua varibel kinerja jalan. Berikut merupakan variabel dan definisi operasional variabel.

Tabel 4. Definisi Operasional Variabel

\begin{tabular}{|l|l|}
\hline \multicolumn{1}{|c|}{ Variabel } & \multicolumn{1}{c|}{ Definsi operasional } \\
\hline On street parking & \multicolumn{1}{|c|}{$\begin{array}{l}\text { Volume parkir adalah jumlah kendaraan yang termasuk dalam beban parkir (yaitu jumlah kendaraan per } \\
\text { periode waktu tertentu) }\end{array}$} \\
\hline Volume Parkir & Kapasitas ruang parkir merupakan kemampuan maksimum ruang tersebut dalam menampung kendaraan. \\
\hline Kapasitas Parkir & Lama waktu parkir atau durasi adalah lama waktu yang dihabiskan oleh pemarkir pada ruang parkir. \\
\hline Durasi Parkir & Sudut parkir adalah derajat kemiringan kendaraan menggunakan ruang parkir. \\
\hline Kinerja Jalan & $\begin{array}{l}\text { Volume lalu lintas menunjukan jumlah kendaraan yang melintasi satu titik pengamatan dalam satu satuan } \\
\text { waktu (hari, jam, menit) }\end{array}$ \\
\hline Kolume & $\begin{array}{l}\text { Arus lalu lintas (stabil) maksimum yang dapat dipertahankan pada kondisi tertentu (geometri, distribusi arah } \\
\text { dan komposisi lalu lintas, faktor lingkungan). }\end{array}$ \\
\hline Kapasitas Jalan
\end{tabular}

Sumber : Burhani, Muhammad Anwan, dkk.

Metode pengumpulan data menggunakan tiga cara yaitu kuesioner, observasi lapangan dan wawancara. Kuesioner ditujukan untuk petugas parkir yang berguna untuk mengetahui karakteristik on street parking di Jalan Pemuda. Onservasi lapangan meliputi traffic counting. Traffic counting dilakukan pada titik masuk dan titik keluar Jalan Pemuda Kota Magelang. Wawancara ditujukan kepada Dinas Perhubungan Kota Magelang. Wawancara ke Dinas Perhubungan Kota Magelang berfungsi untuk mengetahui kondisi parkir dan lalu lintas Kota Magelang, kebijakan, keberjalanan kebijakan, dan beberapa rencana tentang on street parking kawasan komersial.

Wilayah penelitian adalah kawasan komersial di Jalan Pemuda Kota Magelang. Kawasan komersial di koridor Jalan Pemuda Kota Magelang yang berada di Kelurahan Rejowinangun Utara, Kemirirejo, dan Pajang. Peta wilayah penelitian penelitian dapat dilihat pada gambar 1 waktu penelitian adalah ketika penelitian berlangsung. 


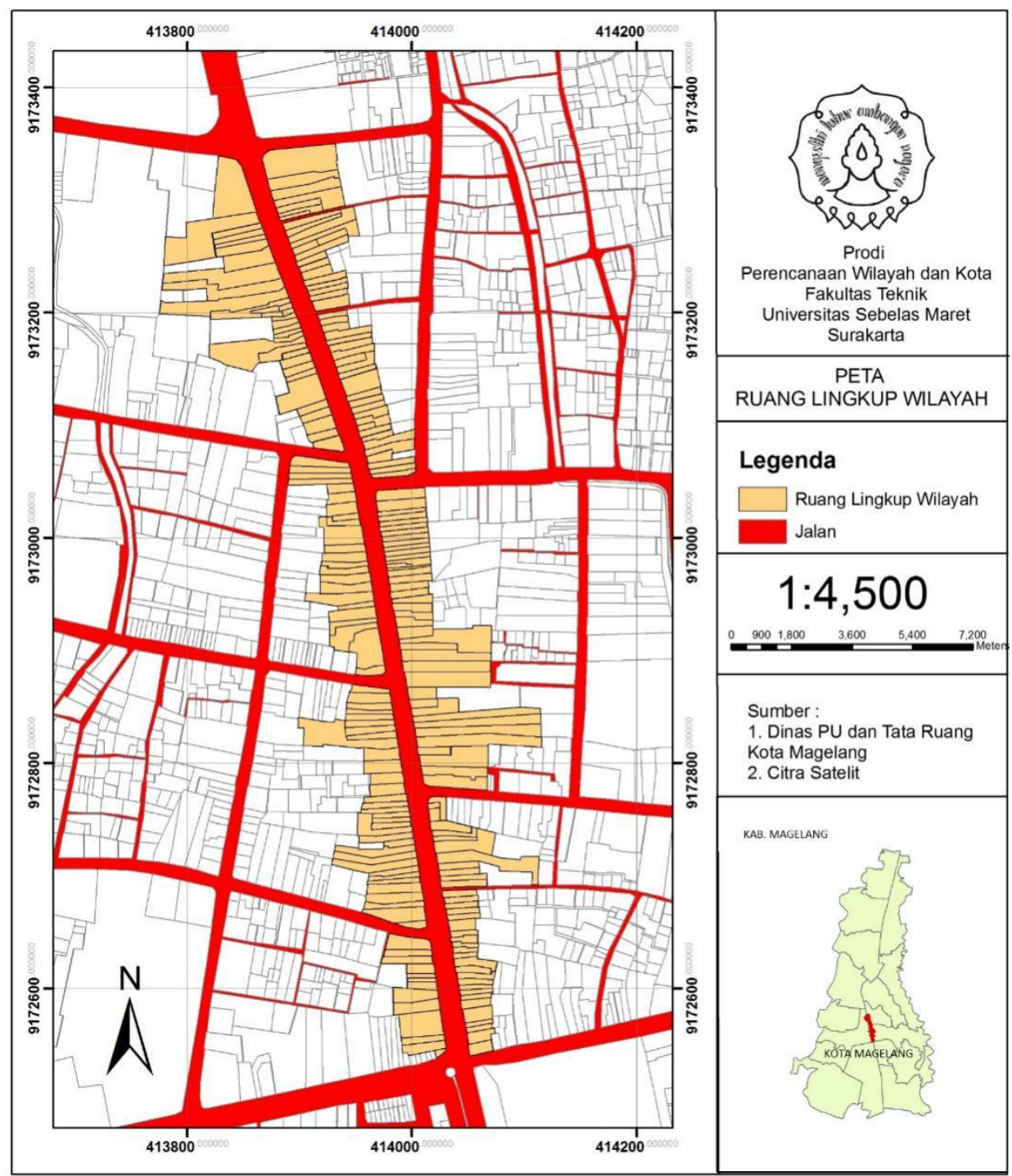

Gambar 1. Wilayah Penelitian

\section{HASIL DAN PEMBAHASAN}

Berdasarkan tujuan penelitian yaitu mengetahui potensi gangguan on street parking terhadap kinerja jalan, pada kawasan komersial, dilakukan dua tahapan perhitungan yaitu perhitungan on street parking, dan kinerja jalan. Potensi gangguan on street parking pada kawasan komersial terhadap kinerja jalan kemudian dianalisis dengan proses triangulasi metode pengumpulan data. Berikut merupakan hasil dan pembahasan masing-masing sasaran tersebut.

\subsection{ANALISIS ON STREET PARKING}

Analisis on street parking didasarkan pada variabel-variabel yang telah ditentukan. Variabel-variabel tersebut terdiri dari 4 variabel on street parking yaitu volume parkir, kapasitas parkir, durasi parkir, dan sudut parkir.

- Volume parkir

Volume parkir didapat dari kuesioner petugas parkir. Volume parkir yang didapatkan adalah volume parkir rata-rata dan volume parkir puncak. Persentase volume parkir dihitung dengan membandingkan volume parkir dengan kapasitas parkir. Perhitungan persentase volume parkir dapat dilihat sebagai berikut.

$\mathrm{VP}=455 / 610 \times 100 \%=74,6 \%$ (Volume rata rata motor)

$\mathrm{VP}=55 / 89 \times 100 \%=61,8 \%$ (Volume rata rata mobil)

$\mathrm{VP}=635 / 610=104,1 \%$ (Volume puncak parkir motor)

$\mathrm{VP}=78 / 89=87,6 \%$ (Volume puncak parkir mobil) 
Volume rata-rata parkir dibandingkan kapasitas parkir motor adalah $74,6 \%$ dan mobil $61,8 \%$ dan volume puncak motor $104,1 \%$ dan mobil 87,6\%. Waktu puncak parkir terjadi pukul 10:30 dan pukul 15:00. Volume puncak parkir kapasitas parkir tidak mampu menampung parkir dengan ditandainya volume parkir lebih besar dari kapasitas parkir.

- Kapasitas Parkir

Kapasitas parkir dihitung kapasitas parkir efektif per jam. Data ini diperoleh dari kuesioner petugas parkir. Kapasitas parkir efektif dapat dilihat sebagai berikut.

Tabel 5. Kapasitas Parkir Efektif per Jam Mobil

\begin{tabular}{|c|c|c|c|c|c|c|c|}
\hline Durasi & & \multirow{2}{*}{10 menit } & \multirow{2}{*}{30 menit } & \multirow{2}{*}{1 jam } & \multirow{2}{*}{2 jam } & \multirow{2}{*}{3 jam } & \multirow{2}{*}{ Jumlah } \\
\hline \multicolumn{2}{|c|}{ Jumlah Petak } & & & & & & \\
\hline Mobil & 89 & 32 & 55 & 32 & 10 & 2 & 131 \\
\hline
\end{tabular}

Sumber : Burhani, Muhammad Anwan, dkk.

Tabel 6. Kapasitas Parkir Efektif per Jam Motor

\begin{tabular}{|l|c|c|c|c|c|c|c|}
\hline \multicolumn{2}{|c|}{ Durasi Parkir } & \multirow{2}{*}{10 menit } & 30 menit & $\mathbf{1}$ jam & $\mathbf{2}$ jam & 3 jam & Jumlah \\
\cline { 1 - 7 } Jumlah Petak & & 378 & 220 & 67 & 10 & 895 \\
\hline
\end{tabular}

Sumber : Burhani, Muhammad Anwan, dkk.

$\mathrm{SRP}=131+895=1026 \mathrm{SRP}$

Kapasitas parkir efektif kemudian dibandingkan dengan kebutuhan parkir berdasarkan Permen PU

$\mathrm{SRP}=0,725 \times \mathrm{LLB} / 100+52.176$

$\mathrm{SRP}=0,725 \times 3.143,75+52.176=2.331$

Tabel 7. Selisih Ruang Parkir Eksisting dengan Kebutuhan Parkir

\begin{tabular}{|c|c|}
\hline Ruang Parkir Eksisting (SRP) & Kebutuhan Ruang Parkir (SRP) \\
\hline 1.026 & 2.331 \\
\hline Selisih & 1305 \\
\hline
\end{tabular}

Sumber : Burhani, Muhammad Anwan, dkk.

Dari tabel perbandingan kebutuhan parkir dapat dilihat bahwa kebutuhan ruang parkir belum dapat terpenuhi. Hal ini ditunjukkan dengan adanya ruang parkir di lokasi sebesar 1.026 dan kebutuhan ruang parkir 2.331.

- Durasi Parkir

Data durasi parkir didapat melalui kuesioner petugas parkir. Dari kuesioner tersebut mendapatkan hasil sebagai berikut.

Tabel 8. Presentase Persebaran Durasi Parkir

\begin{tabular}{|l|l|l|}
\hline \multicolumn{1}{|c|}{ Waktu } & Persentase & \multicolumn{1}{c|}{ Nilai tingkat gangguan } \\
\hline 10 menit & $6 \%$ & Gangguan tinggi \\
\hline 30 menit & $31 \%$ & Gangguan cukup tinggi \\
\hline 1 jam & $36 \%$ & Gangguan sedang \\
\hline 2 jam & $22 \%$ & Gangguan cukup rendah \\
\hline$\geq 3$ jam & $5 \%$ & Gangguan rendah \\
\hline
\end{tabular}

Sumber : Burhani, Muhammad Anwan, dkk.

Gangguan terhadap kinerja jalan dipengaruhi oleh manuver. Semakin singkat pengendara parkir maka semakin terganggu pula kinerja jalan. Dari tabel tersebut selama kurang dari 1 jam menunjukkan ada $73 \%$ pergantian. Pergantian parkir ini termasuk besar karena dalam waktu satu jam terdapat kendaraan yang masuk dan keluar ruang parkir sebesar $73 \%$. 
- Sudut Parkir

Sudut parkir di Jalan Pemuda adalah $60^{\circ}$ untuk mobil dan $90^{\circ}$ untuk motor. Berikut merupakan analisisnya.

Tabel 9. Kriteria On Street Parking

\begin{tabular}{|c|c|c|c|c|c|c|}
\hline $\begin{array}{c}\text { Sudut } \\
\text { Parkir }\left({ }^{\circ}\right)\end{array}$ & $\begin{array}{c}\text { Lebar ruang } \\
\text { parkir }(\mathbf{m})\end{array}$ & $\begin{array}{c}\text { Ruang Parkir } \\
\text { Efektif }(\mathrm{m})\end{array}$ & $\begin{array}{c}\text { Ruang } \\
\text { Manuver }(\mathrm{m})\end{array}$ & $\mathbf{D}+\mathbf{M}(\mathbf{m})$ & $\mathbf{D}+\mathbf{M}-\mathrm{J}(\mathbf{m})$ & Keterangan \\
\hline $0^{\circ}$ & 2,3 & 2,3 & 3,0 & 5,3 & 2,8 & Gangguan Rendah \\
\hline $30^{\circ}$ & 2,5 & 4,5 & 2,9 & 7,4 & 4,9 & Gangguan Cukup Rendah \\
\hline $45^{\circ}$ & 2,5 & 5,1 & 3,7 & 8,8 & 6,3 & Gangguan Sedang \\
\hline $60^{\circ}$ & 2,5 & 5,3 & 4,6 & 9,9 & 7,4 & Gangguan Cukup Tinggi \\
\hline $90^{\circ}$ & 2,5 & 5,0 & 5,8 & 10,8 & 8,3 & Gangguan Tinggi \\
\hline
\end{tabular}

Sumber : Burhani, Muhammad Anwan, dkk.

Dari tabel tersebut juga dapat dianalisis lebih lanjut sebagai berikut.

Tabel 10. Analisis On Street Parking

\begin{tabular}{|c|c|c|}
\hline Aspek (Sudut $60^{\circ}$ ) & Jalan Pemuda Kota Magelang & Pedoman Teknis Penyelenggaraan Fasilitas Parkir \\
\hline Lebar Parkir & 4 meter & 5,3 meter \\
\hline Ruang Manuver & Memakai ruas jalan & 4,6 meter \\
\hline Ruas Jalan Efektif & $10,5-7,4=3,1$ meter & $\begin{array}{l}\text { Lebar jalan - (OSP + Manuver - J). Ruas jalan efektif } \\
\text { dapat menampung volume rata rata atau lebih besar. }\end{array}$ \\
\hline
\end{tabular}

Sumber : Burhani, Muhammad Anwan, dkk.

Pada tabel tersebut dapat diketahui bahwa gangguan akibat on street parking adalah cukup tinggi dengan parkir memakan badan jalan sebesar 1,3 meter, ruang manuver memakai ruas jalan dan ruas jalan efektif sebesar 3,1 meter (30\% lebar jalan). Besar sudut parkir ini berpengaruh terhadap besar lebar efektif jalan sesuai dengan Direktorat Jenderal Perhubungan Darat (1998) sudut parkir berpengaruh dalam banyaknya ruang yang dibutuhkan untuk parkir dan manuver.

\subsection{ANALISIS KINERJA JALAN}

Analisis kinerja jalan didasarkan pada variabel-variabel yang telah ditentukan. Variabel-variabel tersebut adalah volume lalu lintas pada waktu puncak dan kapasitas jalan.

Volume lalu lintas didapatkan melalui observasi lapangan selama 2 jam $\mathrm{x} 4$ waktu (pagi, siang, sore dan malam), survey dilaksanakan pada jam 06:30 - 08:30, 10:00 - 12:00, 14:00 - 16:00 dan jam 18:30 - 20:30. Jumlah kendaraan yang melintasi Jalan Pemuda Kota Magelang sebesar 31.188. Gambar 2 memperlihatkan komposisi volume kendaraan yang melintasi Jalan Pemuda Kota Magelang

\section{Komposisi Kendaraan}

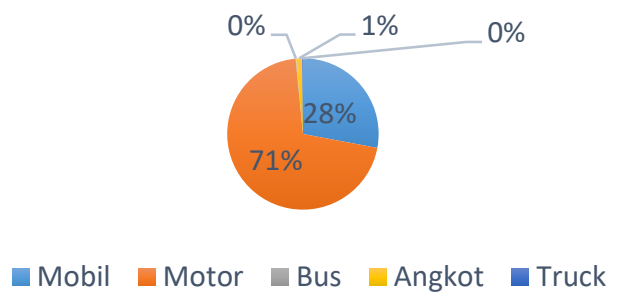

Sumber : Burhani, Muhammad Anwan, dkk.

Gambar 2. Komposisi Volume Kendaraan yang Melintasi Jalan Pemuda Kota Magelang

Dari gambar 2 tersebut dapat dilihat bahwa jumlah motor yaitu sebanyak 21990 atau sebesar $71 \%$, diikuti mobil sebesar 8719 dengan proporsi kendaraan 28\%, angkutan umum sebanyak 382 dengan proporsi $1 \%$, serta truk dan bus sebanyak 61 dan 36 dengan proporsi $0 \%$. Untuk mengetahui persebaran rata-rata volume lalu lintas dalam sehari dapat dilihat dalam gambar 3 . 


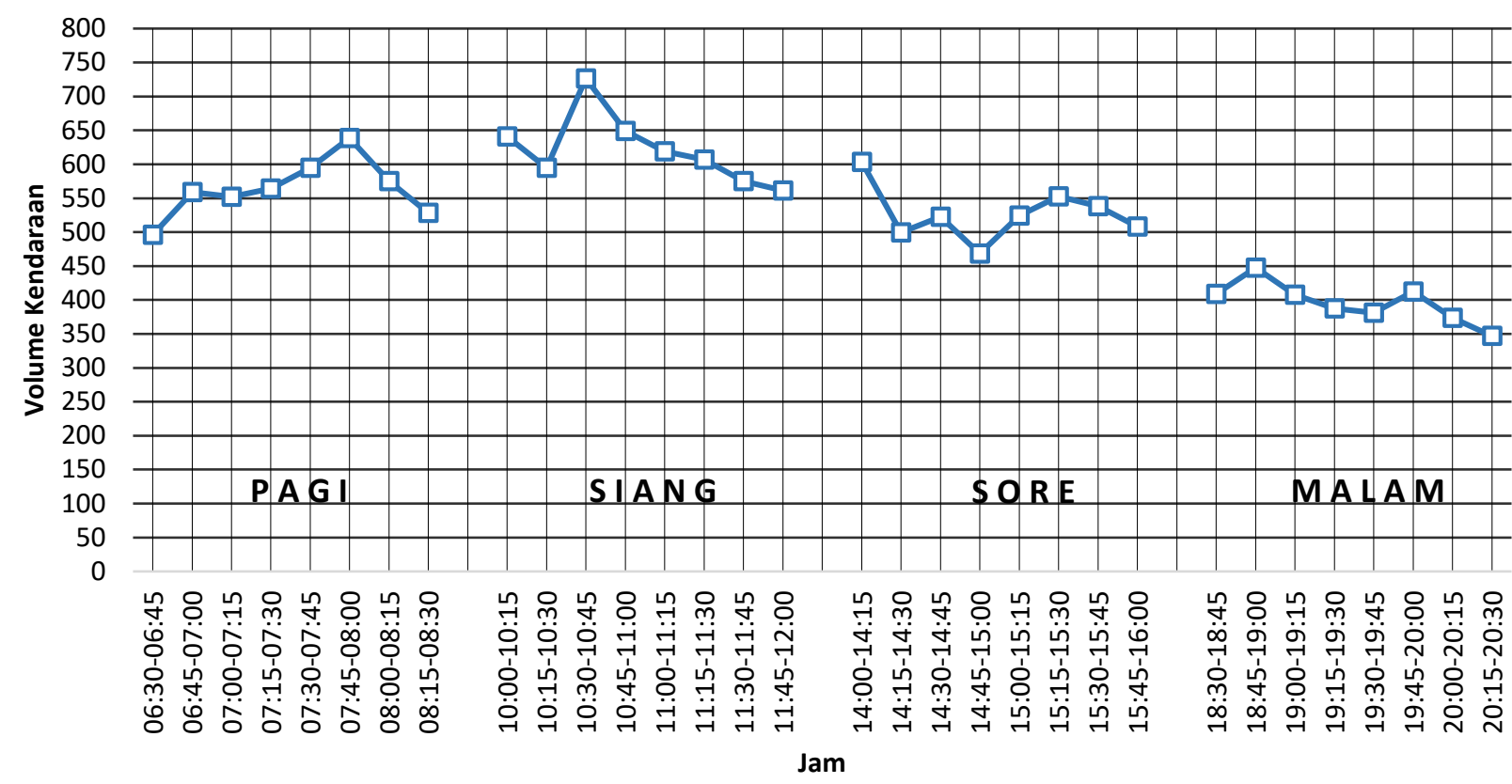

Sumber : Burhani, Muhammad Anwan, dkk.

Gambar 3. Rata rata Volume Kendaraan Jalan Pemuda Kota Magelang

Dari gambar tersebut diketahui bahwa volume tertinggi terdapat pada waktu siang hari antara jam 10:00-12:00 dengan puncak tertinggi lebih dari $700 \mathrm{smp}$ yaitu pada jam 10:30-10:45. Kapasitas jalan didapat melalui observasi lapangan. Kapasitas jalan ini dihitung kapasitas jalan dengan on street parking dan kapasitas jalan tanpa on street parking. Perhitungan ini dimaksudkan untuk mengetahui besaran gangguan yang diakibatkan oleh on street parking. Kapasitas jalan dapat diketahui melalui perhitungan sebagai berikut.

$C=3300 \times 0.96 \times 1 \times 0.96 \times 0.90=2737.152 \mathrm{smp} / \mathrm{jam}$ (ada on street parking)

$\mathrm{C}=4950 \times 1 \times 1 \times 0.84 \times 0.90=3742.2 \mathrm{smp} / \mathrm{jam}$ (tanpa on street parking)

Dari hasil observasi, dapat diketahui bahwa terdapat perbedaan kapasitas jalan dengan on street parking dan kapasitas jalan tanpa on street parking. Perbedaan kapasitas ini disebabkan karena adanya perbedaan lebar jalan.

\subsection{ANALISIS POTENSI GANGGUAN AREA ON STREET PARKING PADA KAWASAN KOMERSIAL TERHADAP KINERJA JALAN}

Analisis ini menggambarkan mengenai derajat kejenuhan Jalan Pemuda Kota Magelang beserta gangguan akibat on street parking. Derajat kejenuhan Jalan Pemuda Kota Magelang dapat diketahui sebagai berikut.

Tabel 11. Perbandingan Derajat Kejenuhan antara Ada On Street Parking dan Tanpa On Street Parking

\begin{tabular}{|c|c|c|c|c|}
\hline \multirow{2}{*}{ No. } & \multicolumn{2}{|c|}{ Waktu } & \multirow{2}{*}{$\begin{array}{c}\text { Tingkat } \\
\text { Pelayanan }\end{array}$} & \multirow[t]{2}{*}{ Karakteristik } \\
\hline & Ada OSP & Tanpa OSP & & \\
\hline 1. & - & MALAM & B & $\begin{array}{l}\text { Arus stabil tetapi kecepatan operasi mulai dibatasi oleh lalu lintas, } \\
\text { pengemudi memliki kebebasan yang cukup untuk memilih kecepatan }\end{array}$ \\
\hline 2. & MALAM & $\begin{array}{l}\text { PAGI } \\
\text { SIANG } \\
\text { SORE }\end{array}$ & C & Arus stabil, akan tetapi kecepatan dan gerak kendaraan dikendalikan \\
\hline 3. & SORE & - & $\mathrm{D}$ & $\begin{array}{l}\text { Arus mendekati tidak stabil, kecepatan masih di kendalikan, V/C masih } \\
\text { dapat di tolerir }\end{array}$ \\
\hline 4. & $\begin{array}{l}\text { PAGI } \\
\text { SIANG }\end{array}$ & - & $\mathrm{E}$ & $\begin{array}{l}\text { Volume lalu lintas mendekati atau berada pada kapasitas, arus tidak } \\
\text { stabil, kecepatan terkadang terhenti }\end{array}$ \\
\hline
\end{tabular}

Sumber : Burhani, Muhammad Anwan, dkk. 
Nilai derajat kejenuhan tertinggi dengan ada on street parking terjadi pada pagi dan siang hari dengan nilai derajat kejenuhan E. Nilai E menandakan perlu adanya rencana transportasi, supaya arus kendaraan stabil (C) atau lebih baik kinerja jalannya. Nilai derajat kejenuhan tanpa ada on street parking memiliki nilai $C$. Nilai $C$ adalah nilai ideal dan arus kendaraan stabil. Dari analisis yang telah dilakukan sebelumnya dapat dilihat potensi gangguan on street parking pada kawasan komersial terhadap kinerja jalan sebagai berikut

Tabel 12. Potensi Gangguan Area On street parking Kawasan Komersial Terhadap Kinerja Jalan

\begin{tabular}{|c|c|c|c|c|c|c|c|c|c|}
\hline \multirow{3}{*}{ Waktu } & \multirow{2}{*}{\multicolumn{2}{|c|}{$\begin{array}{c}\text { Derajat } \\
\text { Kejenuhan }\end{array}$}} & \multicolumn{7}{|c|}{ Potensi Gangguan } \\
\hline & & & \multirow{2}{*}{$\begin{array}{c}\text { Waktu } \\
\text { Puncak } \\
\text { Parkir }\end{array}$} & \multicolumn{2}{|c|}{ Voume parkir } & \multirow{2}{*}{$\begin{array}{l}\text { Lebar } \\
\text { Jalan } \\
\text { Efektif }\end{array}$} & \multirow{2}{*}{$\begin{array}{c}\text { Jalan } \\
\text { Terganggu } \\
\text { Manuver }\end{array}$} & \multirow{2}{*}{$\begin{array}{c}\text { Jalan } \\
\text { Terganggu } \\
\text { Parkir }\end{array}$} & \multirow[b]{2}{*}{ Durasi Parkir } \\
\hline & $\begin{array}{c}\text { Tanpa } \\
\text { OSP }\end{array}$ & $\begin{array}{l}\text { Ada } \\
\text { OSP }\end{array}$ & & Puncak & $\begin{array}{l}\text { Rata } \\
\text { rata }\end{array}$ & & & & \\
\hline Pagi & C & $\mathrm{E}$ & - & & \multirow{4}{*}{$\begin{array}{l}74,6 \% \\
\text { motor } \\
61,8 \% \\
\text { mobil }\end{array}$} & \multirow{4}{*}{$\begin{array}{c}3,1 \\
\text { meter }\end{array}$} & \multirow{4}{*}{ 4,6 meter } & \multirow{4}{*}{ 1,3 meter } & \multirow{4}{*}{$\begin{array}{c}10 \text { menit }=6 \% \\
30 \text { menit }=31 \% \\
1 \text { jam }=36 \% \\
2 \text { jam }=22 \% \\
\geq 3 \text { jam }=5 \%\end{array}$} \\
\hline Siang & C & $E$ & $46 \%$ & $\begin{array}{c}104,1 \% \\
\text { motor }\end{array}$ & & & & & \\
\hline Sore & C & D & $45 \%$ & $\begin{array}{c}87,6 \% \\
\text { mobil }\end{array}$ & & & & & \\
\hline Malam & $B$ & $C$ & - & & & & & & \\
\hline Lainnya & & & $9 \%$ & & & & & & \\
\hline
\end{tabular}

Sumber : Burhani, Muhammad Anwan, dkk.

Berdasarkan tabel 11 dapat dilihat bahwa nilai gangguan terbesar parkir terdapat di siang hari, dan di sore hari. Pada pagi hari derajat kejenuhan bernilai $\mathrm{E}$ namun jalan cenderung lancar karena masih sedikit volume on street parking bahkan tidak ada on street parking. Terdapat perbedaan nilai derajat kejenuhan yang disebabkan oleh pengurangan lebar jalan sesuai yang dinyatakan Tamin (2000) bahwa parkir di badan jalan akan mengurangi kapasitas jalan. Waktu puncak parkir siang dan sore dengan persebaran di siang hari sebesar $46 \%$ dan di sore hari sebesar $45 \%$, sedangkan $9 \%$ berada pada jam di luar penelitian. Volume puncak parkir sudah melebihi kapasitas pada jam pucak parkir ditandai dengan volume puncak parkir motor hingga 104,1\% dan mobil 87,6\%.

Ruas jalan efektif sebesar 3,1 meter (30\% lebar jalan), artinya sebesar 7,4 (70\% lebar jalan) digunakan untuk parkir dan ruang manuver kendaraan. Pada jam sibuk lebar jalan menjadi terganggu karena kendaraan yang bermanuver dan durasi parkir yang singkat. Gangguan parkir akibat durasi parkir ini dalam 1 jam terdapat $73 \%$ volume kendaraan yang masuk dan keluar petak parkir. Pernyataan Tamin (2000) yaitu pengurangan lebar jalan disebabkan adanya proses kendaraan masuk dan keluar petak parkir. Fasilitas parkir di rumija harus dapat menjamin keamanan, keselamatan dan kelancaran lalu lintas (Perda Kota Magelang No 15 Tahun 2012). Pernyataan ini tidak sesuai dengan kondisi eksisting di Jalan Pemuda Kota Magelang. Di Jalan Pemuda Kota Magelang kondisi parkir mengganggu kinerja jalan yang dibuktikan dengan nilai derajat kejenuhan $E$ pada pagi dan siang hari, nilai $D$ pada sore hari. Pada malam hari kinerja jalan tidak berpengaruh dengan keberadaan on street parking. Penundaan ini ditimbulkan oleh macetnya kendaraan pada simpang jalan yang ramai, lebar jalan yang kurang, parkir-parkir mobil dijalan sempit dan sebagainya (Fauzia, 2013). Pernyataan ini jika disesuaikan dengan kondisi di Jalan Pemuda Kota Magelang terjadi penyempitan jalan karena adanya on street parking (parkir dibadan jalan). Tanpa ada on street parking maka lebar jalan akan lebih besar, sehingga lebar jalan tidak dapat berdiri sendiri namun dipengaruhi oleh on street parking. Data tersebut didukung oleh pernyataan dari Dinas Perhubungan Kota Magelang.

"Kemacetan terjadi di simpang Canguk, simpang Trio dan Jalan Pemuda. Kemacetan ini disebabkan karena adanya peningkatan penggunaan kendaraan bermotor, geometrik simpang dan gangguan samping berupa parkir di kawasan komersial. (Kepala Bidang Lalu Lintas dan Perparkiran Dishub Kota Magelang)."

Dikemukakan juga oleh Kasi Manajemen dan Rekayasa Lalu Lintas sebagai berikut.

"Penumpukan volume kendaraan di Kota Magelang terjadi di Jalan Pemuda (kawasan komersial), Jalan Uripsumoharjo dengan Jalan Sukarno-Hatta (simpang canguk). Kemacetan di Jalan Pemuda disebabkan oleh parkir dan di simpang Canguk karena karakteristik simpang (Kasi Manajemen dan Rekayasa Lalu Lintas Dishub Kota Magelang)." 
Selain itu dikemukakan juga oleh Staff Seksi Angkutan Dishub Kota Magelang.

"Di Jalan Pemuda (pecinan), sering terjadi kemacetan, hal ini disebabkan karena parkir (on street parking), peningkatan volume kendaraan terutama ketika liburan dan hujan di pagi hari (Staff Seksi Angkutan Dishub Kota Magelang)."

Interview dari Dinas Perhubungan Kota Magelang menegaskan bahwa salah satu nilai VCR yang tinggi sehingga menyebabkan kemacetan salah satunya berlokasi di Jalan Pemuda. Lokasi kemacetan ini diakibatkan oleh parkir di badan jalan yang kurang tertib, kurangnya kapasitas parkir dari permintaan yang ada dan karakteristik simpang. Dari interview tersebut dapat disimpulkan bahwa on street parking di Jalan Pemuda mengakibatkan menurunnya kinerja jalan sudah disadari. Sehingga muncul rencana-rencana sebagai berikut.

"Belum ada lahan yang dapat digunakan untuk kegiatan tersebut, namun sudah ada wacana parkir terpadu di area alun-alun dan kawasan MT (halaman parkir eks Magelang Teater) (Kepala Bidang Lalu Lintas dan Perparkiran Dishub Kota Magelang)."

Rencana pemindahan parkir juga dikemukakan oleh Kasi Manajemen dan Rekayasa Lalu Lintas Dinas Perhubungan Kota Magelang sebagai berikut.

"Tidak ada lahan lagi untuk membuat off street parking, namun ada wacana dari walikota bahwa Jalan Pemuda akan dijadikan kawasan city walk tapi belum tahu kapan. On street parkingnya akan dipindah ke belakang Jalan Pemuda (Kasi Manajemen dan Rekayasa Lalu Lintas Dishub Kota Magelang)."

Hal ini juga dikemukakan oleh Staff Seksi Angkutan Dishub Kota Magelang.

"Pernah ada rencana membangun gedung parkir di MT dan parkir dipindahkan ke jalan yang menuju Jalan Pemuda yang kelas jalannya lebih rendah (Staff Seksi Angkutan Dishub Kota Magelang)."

Gangguan area on street parking yang mengakibatkan menurunnya kinerja jalan yang telah disadari oleh pemerintah memunculkan rencana yaitu membangun gedung parkir komunal di Magelang Teater, Alun-Alun Kota Magelang dan rencana pemindahan parkir di jalan yang menuju Jalan Pemuda yang kelas jalannya lebih rendah. Gangguan on street parking terhadap menurunnya kinerja jalan disebabkan besaran sudut parkir. Sudut parkir akan menentukan lebar jalan efektif, semakin besar sudut parkir maka semakin kecil lebar jalan efektif. Sudut parkir ini akan berkaitan dengan volume parkir dan durasi parkir. Keterkaitan tersebut berupa tingkat keseringan kendaraan masuk dan keluar petak parkir. Semakin sering dan semakin banyak kendaraan masuk keluar petak parkir maka gangguan yang ditimbulkan terhadap kinerja jalan semakin tinggi sehingga menyebabkan menurunnya kinerja jalan.

\section{KESIMPULAN}

Perkembangan aktivitas komersial di Jalan Pemuda setiap tahunnya selalu mengalami peningkatan baik dari luas lantainya, jumlah komunitas dan lahan yang beralih fungsi ke kawasan komersial. Hal ini tentunya akan menimbulkan tarikan yang lebih besar dikemudian hari sehingga membutuhkan ruang parkir yang lebih luas. Parkir yang terdapat di Jalan Pemuda adalah on street parking dengan sudut $60^{\circ}$. Sudut parkir $60^{\circ}$ membutuhkan ruang manuver yang besar sehingga mengganggu kinerja jalan. Potensi gangguan gangguan on street parking pada kawasan komersial terhadap kinerja jalan digunakan analisis triangulasi metode pengumpulan data. Pada tabel 12 merupakan ringkasan triangulasi dengan metode pengumpulan data.

Tabel 13. Ringkasan Triangulasi Metode Pengumpulan Data

\begin{tabular}{|c|c|c|c|c|c|c|}
\hline Masalah & Wawancara & \multicolumn{3}{|c|}{ Observasi Lapangan } & \multicolumn{2}{|c|}{ Kuesioner } \\
\hline \multirow{4}{*}{$\begin{array}{l}\text { Potensi } \\
\text { gangguan on } \\
\text { street parking } \\
\text { pada kawasan } \\
\text { komersial }\end{array}$} & \multirow{4}{*}{$\begin{array}{l}\text { - Potensi kemacetan } \\
\text { a. Jalan Pemuda } \\
\text { b. Simpang Canguk } \\
\text { c. Simpang Trio } \\
\text { - Penyebab Kemacetan }\end{array}$} & \multicolumn{3}{|c|}{ - Derajat kejenuhan } & \multicolumn{2}{|c|}{ - Durasi Parkir } \\
\hline & & Waktu & $\begin{array}{l}\text { Ada } \\
\text { OSP }\end{array}$ & $\begin{array}{l}\text { Tanpa } \\
\text { OSP }\end{array}$ & Waktu & Prosentase \\
\hline & & Pagi & $E$ & $\mathrm{C}$ & 10 menit & $6 \%$ \\
\hline & & Siang & $E$ & C & 30 menit & $31 \%$ \\
\hline
\end{tabular}




\begin{tabular}{|c|c|c|c|c|c|c|}
\hline \multirow{4}{*}{$\begin{array}{l}\text { terhadap kinerja } \\
\text { jalan }\end{array}$} & \multirow[b]{4}{*}{$\begin{array}{l}\text { a. On street parking di } \\
\text { kawasan komersial } \\
\text { (Jalan Pemuda). } \\
\text { b. Peningkatan volume } \\
\text { kendaraan } \\
\text { c. Karakteristik simpang } \\
\text { (di simpang Canguk } \\
\text { dan simpang Trio) } \\
\text { - Rencana di Jalan } \\
\text { Pemuda } \\
\text { a. Parkir terpadu di alun } \\
\text { alun dan kawasan MT } \\
\text { (Magelang Teater) } \\
\text { b. Parkir akan } \\
\text { dipindahkan ke kelas } \\
\text { jalan yang lebih } \\
\text { rendah } \\
\text { c. Kawasan komersial } \\
\text { Jalan Pemuda Kota } \\
\text { Magelang } \\
\text { diwacanakan menjadi } \\
\text { city walk }\end{array}$} & Sore & $D$ & $C$ & 1 jam & $36 \%$ \\
\hline & & Malam & $C$ & $B$ & 2 jam & $22 \%$ \\
\hline & & \multirow{2}{*}{\multicolumn{3}{|c|}{$\begin{array}{l}\text { - Sudut on street parking di } \\
\text { Jalan Pemuda Kota } \\
\text { Magelang adalah } 600 \\
\text { dengan lebar jalan } 10,5 \\
\text { meter sehingga dapat } \\
\text { diketahui panjang parkir } \\
7,4 \text { meter ( } 70 \% \text { dari lebar } \\
\text { jalan) dan lebar jalan } \\
\text { efektif } 3,1 \text { meter ( } 30 \% \\
\text { lebar jalan). } \\
\text { - Kebutuhan ruang parkir } \\
\text { dihitung dengan luas lantai } \\
\text { komersial efektif per } 100 \\
\text { m² kebutuhan parkirnya } \\
\text { kurang. }\end{array}$}} & $\geq 3$ jam & $5 \%$ \\
\hline & & & & & \multicolumn{2}{|c|}{$\begin{array}{l}\text { - Volume parkir dibanding kapasitas } \\
\text { parkir saat peak hour (jam } 11 \text { dan jam } \\
\text { 15) adalah } 104,1 \% \text { motor dan } 87,6 \% \\
\text { mobil } \\
\text { - Kecenderungan Parkir } \\
\text { a. Menurun pada tahun } 2013 \text { karena } \\
\text { ada relokasi pedagang kaki lima, } \\
\text { namun perlahan meningkat } \\
\text { perlahan lahan setelah } 2013 \\
\text { b. Menurun karena keberadaan pasar } \\
\text { modern yang berkembang (artos) } \\
\text { pada tahun } 2011 \\
\text { c. Ada peningkatan terutama pada } \\
\text { hari libur sekolah hingga ada } \\
\text { pengelolaan khusus }\end{array}$} \\
\hline
\end{tabular}

Sumber : Burhani, Muhammad Anwan, dkk.

Dari tabel tersebut dapat diketahui bahwa di Jalan Pemuda Kota Magelang terjadi kemacetan yang disebabkan oleh on street parking di kawasan komersial. Potensi kemacetan akibat on street parking di Jalan Pemuda Kota Magelang sudah diketahui oleh Pemerintah Daerah terutama Dinas Perhubungan Kota Magelang. Keadaan on street parking yang mengganggu kinerja jalan memunculkan rencana adanya pembangunan parkir terpadu di Alun-Alun Kota Magelang dan di Magelang Teater. Pernyataan dari Dinas Perhubungan didukung dengan perhitungan kuantitatif on street parking dan kinerja jalan. Perhitungan tersebut berupa sudut parkir, kebutuhan ruang parkir, dan kebutuhan ruang parkir. Kinerja jalan pada pagi dan siang hari di Jalan Pemuda Kota Magelang memiliki nilai derajat kejenuhan $E$ yang berarti harus ada inovasi untuk memperbaiki nilai derajat kejenuhan tersebut. Adanya on street parking mengurangi lebar jalan efektif, panjang on street parking memakai lebar jalan sebesar 7,4 meter (70\% dari lebar jalan) dan lebar jalan efektif adalah 3,1 meter (30\% dari lebar jalan). Kebutuhan ruang parkir yang dihitung berdasarkan Permen PU No. 29/PRT/M/2006 kurang 1305 SRP.

On street parking di Jalan Pemuda memiliki karakteristik parkir yang relatif singkat, volume parkir tinggi pada siang dan sore hari, memiliki sudut $60^{\circ}$, dan kecenderungan parkir yang meningkat dari tahun ke tahun meskipun menurun pada tahun 2011 dan 2013. Parkir yang relatif singkat ditandakan dengan kendaraan yang parkir kurang dari 1 jam ada $73 \%$. Hal ini berarti selama 1 jam ada pergantian parkir di Jalan Pemuda Kota Magelang sebanyak $73 \%$ dari volume parkir. Volume dibandingkan kapasitas on street parking di Jalan Pemuda Kota Magelang sebesar $104,1 \%$ motor dan $87,6 \%$ motor. Sedangkan volume rata-rata parkir setiap jam dalam sehari adalah $74,6 \%$ motor dan $61,8 \%$ mobil. Volume on street parking termasuk tinggi ditandainya dengan volume kendaraan yang melebihi kapasitas pada jam puncak parkir di siang dan sore hari. Sudut parkir sebesar $60^{\circ}$, memerlukan ruang manuver yang besar. Berdasarkan perhitungan sudut parkir $60^{\circ}$ mengurangi lebar jalan sebesar 7,4 meter (70\% lebar jalan). Kecenderungan parkir di Jalan Pemuda mengalami penurunan volume parkir pada tahun 2011 dan 2013 dan naik perlahan setelah tahun tersebut. Di tahun 2011 ada pembukaan Armada Town Square dan di tahun 2013 ada penataan kawasan komersial Jalan Pemuda Kota Magelang. Pada hari libur panjang on street parking di Jalan Pemuda dikelola secara khusus karena volume kendaraan yang melebihi kapasitas.

Dari analisis tersebut dapat dilihat bahwa on street parking memiliki potensi yang tinggi untuk mengganggu kinerja jalan. Gangguan tersebut terkategori tinggi karena karakteristik on street parking tersebut, yaitu: sudut parkir $60^{\circ}$, volume on street parking yang tinggi, kapasitas parkir tidak mencukupi dan durasi parkir yang pendek. On street parking di Jalan Pemuda Kota Megelang ini juga tidak sesuai dengan Permen PU No 29/PRT/M/2006. Hal ini diperkuat oleh Perda Kota Magelang No 15 Tahun 2012 yang menyebutkan bahwa on street parking tidak boleh mengganggu kelancaran lalu lintas. Oleh karena itu perlu adanya penanganan kebijakan dari Pemerintah Daerah untuk mengatasinya. 


\section{DAFTAR PUSTAKA}

Dirjen Bina Marga. (1997). Manual Kapasitas Jalan Indonesia. Jakarta: Direktorat Pengembangan Jaringan Jalan

Dirjen Perhubungan Darat. (1998). Pedoman Perencanaan dan Pengoperasian Fasilitas Parkir. Jakarta: Direktorat Bina Sistem Lalu Lintas Angkutan Kota Dirjen Perhubungan Darat.

Djaelani, Zuhriati A., and Heryati. (2013). Penataan Kawasan Koridor Komersial pada Jalan Arteri. Temu IImiah PLBI 2013.

Farida, Nurul. (2013). Penataan Penggal Jalan Pemuda Pecinan Magelang dengan Konsep Pedestrian Mall. Semarang: Tugas Akhir.

Fauzia, Shifa, \& Anita Ratnasari R. (2013). Pengaruh Aktivitas Kawasan terhadap Sirkulasi Lalu Lintas di Kawasan Jalan Pandanaran. Jurnal Teknik PWK.

Gallion, B. Artur Gallion. (1992). Pengantar Perancangan Kota Desa dan Perencanaan Kota. Jakarta: Erlangga.

Ismanto, Andi. (2008). Analisis Kapasitas Parkir Pada Badan Jalan di Kawasan Pusat Bisnis Wilayah Semarang Tengah serta Pengaruhnya terhadap Kinerja Lalu Lintas.

Republik Indonesia. (1996). Keputusan Direktur Jenderal Perhubungan Darat Nomor. 272/Hk.105/Drjd/96 Tentang Pedoman Teknis Penyelenggaraan Fasilitas Parkir. Jakarta.

Republik Indonesia. (2006). Permen PU No. 29/PRT/M/2006 tentang Pedoman Persyaratan Teknis Bangunan Gedung. Jakarta.

Republik Indonesia. (2006). Permen PU No. 34 Tahun 2006 tentang Jalan. Jakarta.

Republik Indonesia. (2012). Perda Walikota Magelang No. 15 Tahun 2012 tentang Penyelenggaraan Fasilitas Parkir. Magelang

Tamin, Ofyar Z. (2010). Perncanaan dan Pemodelan Transportasi. Bandung: ITB.

Wikrama, A.A. Jaya. (2010). Analisis Karakteristik dan Kebutuhan Parkir di Pasar Kreneng. Jurnal Ilmiah Teknik Sipil. 